\title{
Application of PBL Using Laboratory and Mathematical Thinking Ability to Learning Outcomes of General Chemistry Course
}

\author{
Gulmah Sugiharti ${ }^{1}$, Abdul Hamid K. ${ }^{2} \&$ Mukhtar $^{3}$ \\ ${ }^{1}$ Department of Chemistry Education, Faculty of Mathematics and Natural Science, Universitas Negeri Medan, \\ Medan, Indonesia \\ ${ }^{2}$ Department of Building Engineering, Faculty of Engineering, Universitas Negeri Medan, Medan, Indonesia \\ ${ }^{3}$ Department of Mathematics, Faculty of Mathematics and Natural Science, Universitas Negeri Medan, Medan, \\ Indonesia \\ Correspondence: Gulmah Sugiharti, Department of Chemistry Education, Faculty of Mathematics and Natural \\ Science, Universitas Negeri Medan, Medan, Indonesia.
}

\author{
Received: November 11, $2018 \quad$ Accepted: December 20, $2018 \quad$ Online Published: May 29, 2019 \\ doi:10.5539/ies.v12n6p33 \\ URL: https://doi.org/10.5539/ies.v12n6p33
}

\begin{abstract}
The abundance of chemical concepts and general chemistry lessons that tend to be monotonous and have not yet considered the ability of mathematical thinking to cause problems in learning that resulted in low student learning outcomes. The purpose of this research is to know the influence of learning model and mathematical thinking ability toward General Chemistry study result, also interaction between learning model through laboratory usage and mathematical thinking ability. This research is an experimental research using PBL and DI model. The learning result data is obtained from general chemistry study result test and mathematical thinking ability data is obtained through the test of mathematical thinking ability which has all been validated. The data analysis technique used two way analysis of variance (ANOVA). The result of the research shows that there is a significant effect of the learning model on the students 'learning outcomes in the General Chemistry course and there is interaction between the learning model using the laboratory with the ability to think mathematically on the students' General Chemistry students learning outcomes. This research concludes that the PBL model using laboratories is well used in general chemistry learning, and preferably in teaching general chemistry courses, the lecturer considers students' mathematical thinking skills.
\end{abstract}

Keywords: ANOVA $2 \times 2$, learning result, mathematical thinking ability, problem based learning (PBL)

\section{Introduction}

Problems faced by students so far in addition to the lessons that tend to be used by lecturers are still monotonous because they have not considered the ability to think, and students do not have the habit of learning needed to be successful in the study. So far, Chemistry Education Study Program has not maximally produced competent alumni to become professional teachers. This is very clearly visible from the low learning result of General Chemistry course.

General Chemistry Course is one of the compulsory courses for Unimed Chemistry education degree students. From the profile data of the organizers of the General Chemistry course, shows that the results of the General Chemistry course subjects are over $50 \%$ below the standard of graduation (Archival of Chemistry Unimed) (Onder \& Omer, 2006; Nieswandt, 2001; Pinarbasi \& Canpolat, 2003). Chemistry is a difficult subject both by students and teachers. Chemical learning is more focused on scientific concepts and solving problems. In order that the General Chemistry lecture is more optimal, it needs a model of learning that is able to empower the students in the recovery activity. Lessons learned so far have not considered the learning model. The abstracts of chemical concepts and the difficulty of chemicals as (Sihar, 2007), and the limitations of tools and materials in laboratory activities can be overcome with the use of laboratory through virtual lab.

In addition to the commonly used Direct Instruction (DI) model, the Problem Based Learning (PBL) model is expected to solve problems in General Chemistry learning. The aim of the PBL is to give students the knowledge, intrinsic motivation to learn, and experience using effective problem solving, self-learning, and collaboration skills (Whitehill, Bridges, \& Chan, 2014), using student-level PBLs tends to facilitate the development of competent 
graduate students and professional (Beker \& Maunsaiyat, 2014; Blumberg, 2000; Chen, Chang, \& Chiang, 2001).

PBL is a student-centered approach to building problem-solving skills (Louise, Angela, \& Kim, 2017). Problem-based learning emphasizes active learning by guiding students to develop their own understanding and knowledge of a topic through experience and reflection (Hmelo-Silver, 2004; Savery, 2006). PBL is a learning that displays a student-oriented problem with a problem-solving with one correct answer (Anne \& Gary, 2016; Chin \& Chia, 2006). Teaching using PBLs creates more choices in learning (Lancaster et al., 1997; Nowak, 2001). Students had a positive perception of PBL. The findings further confirm the comprehensive benefits of PBL, both in the cognitive and non-cognitive domains. Exploration studies conducted examined the impact of PBL on teachers' technological pedagogical content knowledge (TPACK) and found that the PBL approach creates a critical but safe opportunity for teachers to better understand when using technology (Kalpana \& Hema, 2014).

Success in learning chemistry, in addition to influenced model and laboratory usage, can also be influenced by internal factors in the learning process. One of the internal factors required in General Chemistry learning is the ability to think mathematically. The ability to think mathematically is very necessary in the study of chemistry, especially on the material that is the nature of the calculations are common in general chemistry courses.

In general, students' mathematical thinking ability is not adequate. This is also indicated by the results of the Trend Third International Mathematics and Science Study (TIMSS) survey, the achievement of Indonesian students' achievement in science and low math, the ability of students is still dominant in the initial level or more on the ability to memorize in science and math learning (TIMSS and PIRLS, 2011). For the field of Mathematics, Indonesia was ranked 38 th with a score of 386 from 42 countries. Other facts that show low Indonesian students' reasoning ability are the results of the Program for International Student Assessment (PISA) test, as follows: Indonesia ranks second lowest, in mathematics ability with score 375 , Indonesia has low achievement in mathematics below level 2 working with models for complex systems, students' mathematical thinking and reasoning skills have not been well developed (PISA, 2012).

From the TIMSS and PISA data it can be concluded that students' reasoning and thinking ability is still very low. In relation to that, then the learning process must be improved that is the learning process that should encourage the development of thinking and reasoning students.

Students of the 9 institutions he surveyed showed many deficiencies in aspects of mathematical thinking (Mulhern \& Wylie, 2004).

The aspect of mathematical thinking ability that induces and ways of thinking systematically, also using symbols (Mamoon, 2012). Humans have processes in intelligence that are different from the ability of every human being to have applications in his intelligence in solving problems and creating objects (Gardner, 1993). Ability to think mathematically is logical thinking and analysis as reasoning (Devlin, 2012). Mathematical thinking indicator to be; interpret, analyze, evaluate and infer (Facione, 1994). Teachers involved support student learning should be aware of potential gaps in students' knowledge of the core components of mathematical reasoning, such as estimation, probability, sampling and algebra (Gerry \& Judith, 2004).

The use of laboratory can also support success in General chemistry learning. The use of instructional media, especially the use of laboratory in teaching and learning process can generate motivation and psychological influences to students. In connection with the use of laboratories found no effect of Inkuiri learning model using real laboratory and virtual laboratory on student learning outcomes (Gulmah \& Hasibuan, 2017).

\section{Method}

The sample of this research consists of 26 students in one expoment class and $26 \mathrm{mhs}$ in expriment class 2 . The research design used is the $2 \times 2$ factorialdesign. There are two factors studied namely PBL learning model model using laboratory (A) and ability factor think mathematically (B). Factor A has two levels, namely the PBL learning model using virtual laboratory and DI learning model using virtual laboratory. For factor B there are two levels namely the ability of mathematical thinking high and low. 
Table 1. 2x2 factorial research design

\begin{tabular}{ccc}
\hline \multirow{2}{*}{ Thinking Ability to Learn (B) } & \multicolumn{2}{c}{ Learning Method Using Lab $(\mathrm{A})$} \\
\cline { 2 - 3 } & PBL Virtual Lab $\left(\mathrm{A}_{1}\right)$ & DI Virtual Lab $\left(\mathrm{A}_{2}\right)$ \\
\hline High $\left(\mathrm{B}_{1}\right)$ & $\mathrm{A}_{1} \mathrm{~B}_{1}$ & $\mathrm{~A}_{2} \mathrm{~B}_{1}$ \\
Low $\left(\mathrm{B}_{2}\right)$ & $\mathrm{A}_{1} \mathrm{~B}_{2}$ & $\mathrm{~A}_{2} \mathrm{~B}_{2}$ \\
\hline
\end{tabular}

Note. $\mathrm{A}_{1} \mathrm{~B}_{1}=$ Combination of PBL learning model treatment with virtual lab usage and high mathematical thinking ability. $A_{1} B_{2}=$ Combination of PBL learning model treatment with virtual lab usage and low mathematical thinking ability. $\mathrm{A}_{2} \mathrm{~B}_{1}=$ Combination treatment of DI learning model with the use of virtual laboratory and high mathematical thinking ability. $\mathrm{A}_{2} \mathrm{~B}_{2}=$ Combination treatment of DI learning model with the use of virtual laboratory and low mathematical thinking ability.

\section{Results}

The data collected in this study include: mathematical thinking ability data and general chemistry learning outcomes. Data of this mathematical thinking ability are grouped into 2 categories namely high mathematical thinking ability (26 students) and low mathematical thinking ability also 26 students.

Hypothesis testing is done by testing 2 lines of Analysis of Variance (ANAVA) at $\alpha=0.05$ with the criteria if Fcount $>$ Ftable then Ho is rejected. Based on the calculation of SPS, a description is obtained as shown in Table 2, while the hypothesis testing of general chemistry learning data shows that there is an interaction between mathematical thinking ability (B) and learning model (A) on general chemistry learning outcomes as illustrated in Figure 1. List of anava results learning that is given a combination of treatment learning models using a laboratory and mathematical thinking skills are shown in Table 3.

Table 2. Descriptive statistics

\begin{tabular}{lcccc}
\hline Class & MTA (B) & Mean & Std. Deviation & N \\
\hline \multirow{4}{*}{ PBL Model } & High MTA & 79.6154 & 5.84934 & 13 \\
& Low MTA & 70.7692 & 5.98476 & 13 \\
& Total & 75.1923 & 7.34585 & 26 \\
\multirow{3}{*}{ DI Model } & High MTA & 71.7308 & 5.43758 & 13 \\
& Low MTA & 71.9231 & 5.51077 & 13 \\
& Total & 71.8269 & 5.36459 & 26 \\
\multirow{2}{*}{ Total } & High MTA & 75.6731 & 6.83951 & 26 \\
& Low MTA & 71.3462 & 5.66704 & 26 \\
& Total & 73.5096 & 6.59136 & 52 \\
\hline
\end{tabular}

Table 3. Tests of between-subjects effects

\begin{tabular}{lccccc}
\hline Source & Type III Sum of Squares & Df & Mean Square & F & Sig. \\
\hline Corrected Model & $656.130^{\mathrm{a}}$ & 3 & 218.710 & 6.731 & .001 \\
Intercept & 280990.505 & 1 & 280990.505 & 8647.994 & .000 \\
Class & 147.236 & 1 & 147.236 & 4.531 & 038 \\
KBM & 243.389 & 1 & 243.389 & 7.491 & .009 \\
Class * KBM & 265.505 & 1 & 265.505 & 8.171 & .006 \\
Error & 1559.615 & 48 & 32.492 & & \\
Total & 283206.250 & 52 & & & \\
Corrected Total & 2215.745 & 51 & & &
\end{tabular}

a. R Squared $=.296($ Adjusted R Squared $=.252)$ 


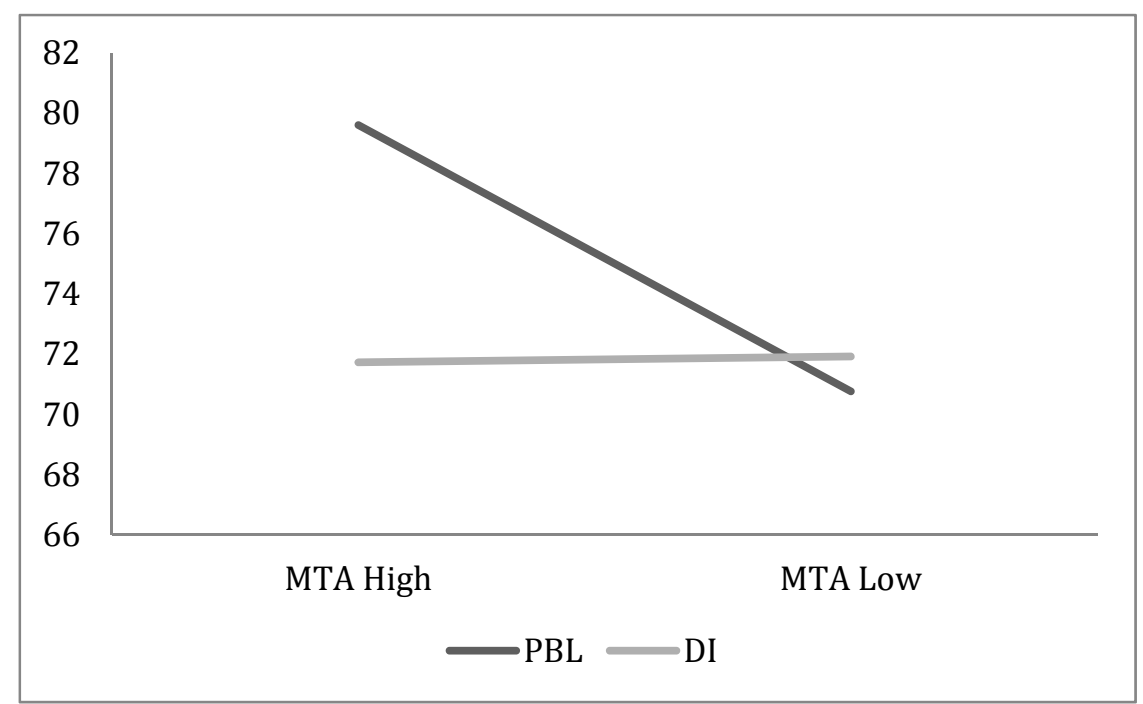

Figure 1. Form of interaction using laboratory learning models (factor A) and Mathematical Thinking Ability (B) on learning outcomes of General Chemistry

\section{Discussion}

1. Fcount $(\mathrm{A})>(0.05)(1 ; 51)$ where $4.531>4.04$ then Ho1 is rejected, there is an influence of PBL learning model by using laboratories on learning outcomes of General Chemistry. The influence shows that the class that is taught by PBL learning model by using a laboratory has an average score of higher learning outcomes that is 75,192 compared to the DI learning model using a laboratory that is 71,827 .

Research found PBL influencing teachers' pre-service TPACK (technological pedagogical content knowledge). The findings of this study seemshows that the design of PBL classes with a conducive emotional and academic environment can stimulate teacher learning (Meng \& Shuh, 2011). PBL give students improved communication skills and critical thinking skills that enable them to more efficiently synthesize information and generate appropriate conclusions (Visconti, 2010). Next, the results of research showed the influence of learning models using the laboratory on student learning outcomes on thermochemical materials with the value Fcount $>$ Ftable that is $4.015>3.99$ (Gulmah \& Bastian, 2018).

2. Fcount $(B)>(0.05)(1: 51)$ where 7.492> 4.04 then Ho2 is rejected, meaning that there is an influence of high mathematical thinking ability and low mathematical thinking ability on learning outcomes of General Chemistry courses. Student learning outcomes data conclude that students who have high mathematical thinking ability provide higher average Chemistry learning outcomes compared to students who have low mathematical thinking skills. The results of this study relate to the research results which found the influence of high logical thinking ability and low logical thinking ability on students' general chemistry learning outcomes on the material of reaction rate (Gulmah \& Hasibuan, 2017). 8 universities in the UK showed a shortage of students in many aspects of mathematical thinking (Mulhern \& Wylie, 2004). Problem-based learning model is a learning model that can encourage students to learn independently and improve thinking skills (J. Kivela \& R. J. Kivela, 2005).

3.Fcount $(\mathrm{AB})>\mathrm{F}(0.05)(1: 15)$ ie $8.171>4.04$ then $\mathrm{Ho} 3$ is rejected means there is an interaction between the learning model using the laboratory with the ability to think mathematically to the General Chemistry learning outcomes. In this study, it was found that if the factor of learning model by using laboratory (factor A) and mathematical thinking ability (factor B) combined, there is an interaction between the two factors that significantly affect student's learning outcomes. This is in line with previous researchinteraction between the learning model with mathematical ability in influencing student learning outcomes (Gulmah, Abdul, \& Mukhtar, 2017).

The result of this research concludes that PBL learning model using laboratory well used in General Chemistry learning. And preferably in learning General Chemistry must consider the ability of student's mathematical thinking.

\section{Acknowledgments}

Acknowledgments to DRPM DIKTI for the support of the doctor's dissertation research (PDD) and the Unimed Leader who has given me permission to study permit. 


\section{References}

Anne, K. H., \& Gary, R. G. (2016). Gifted Middle School Student's Achievement and Perceptions of Science Classroom Quality During Problem-Based Learning. Journal of Advanced Academics, 28(1), 28-50. https://doi.org/10.1177/1932202x16683424

Becker, K. H., \& Maunsaiyat, S. (2004). A Comparison of Students' Achievement and Attitudes between Constructivist and Traditional Classroom Environments in Thailand Vocational Electronics Programs. Journal of Vocational Education Research, 29(2), 133-153. https://doi.org/10.5328/jver29.2.133

Blumberg, P. (2000). Evaluating the evidence that Problem-Based learners are self-directed learners: A review of the literature. In D. H. Evensen, \& E. E. Hmelo (Eds.), Problem-Based Learning: A research perspective on learning interactions (pp. 199-226). Mahwah, NJ: Erlbaum. https://doi.org/10.4324/9781410604989

Chen, S. K., Chang, H. F., \& Chiang, C. P. (2001). Group learning factors in a Problem-Based course in oral radiology. DentoMaxillo Facial Radiology, 30(2), 84-87. https://doi.org/10.1038/sj.dmfr.4600577

Chin, C., \& Chia, L. (2006) Problem-based learning: Using ill-structured problems in biology project work. Science Education, 90, 44-67. https://doi.org/10.1002/sce.20097

Devlin, K. (2012). Mathematical Thinking. Palto Alto: USA.

Facione, A.P. (1994). Holistic Critical Thinking Scoring Rubric. California Academia Press: San Francisco.

Gardner, H. (1993). Frames of mind: The theory of multiple intelligences (2nd ed.). Fontana Press: London.

Gerry, M., \& Judith, W. (2004). Mathematical prerequisites for learning statistics in psychology: assessing core skills of numeracy and mathematical reasoning among undergraduates. Psychology Learning and Teaching, 5(2), 119-132. https://doi.org/10.2304/plat.2005.5.2.119

Gulmah, S., \& Bastian, J. H. (2018). Influence of Learning Model Using Laboratory and Numeric Ability to Student Learning Result on Thermochemical Material. International Education Studies, 11(5), 154-160. https://doi.org/10.5539/ies.v11n5p154

Gulmah, S., \& Hasibuan, S. K. (2017). The Effect of Inquiry Learning Method by Using Laboratory and Logical Thinking on Learning Outcome in Chemical Reaction Rate. Jurnal Pendidikan Kimia, 9(1), 229-235. https://doi.org/10.24114/jpkim.v9i1.6184

Gulmah, S., Abdul, H. K., \& Mukhtar, M. (2017). The Effect of Learning Model and Mathematical Ability into Student's Learning Outcomes in Evaluation Course of Chemistry Education State University of Medan, Procceding of The 2nd Annual Internatioanal Seminar on Transformative Education and Educational Leadership (AISTEEL) Grand Mercure Hotel, 16-17. https://doi.org/10.2991/aisteel-17.2017.61

Hmelo-Silver, C. E. (2004) Problem-based learning: What and how do students learn? Educational Psychology Review, 16(3), 235-266. https://doi.org/10.1023/b:edpr.0000034022.16470.f3

Kalpana, K., \& Hema, P. (2014). Problem-Based Learning: a promising pathway for empowering pre-service teachers for ICT-mediated language teaching. Policy Futures in Education, 12(2). https://doi.org/10.2304/pfie.2014.12.2.262

Kivela, J., \& Kivela, R. J. (2005). Student Perceptions of an embedded problem-based learning instructional approach in a hospitality undergraduate program.International Journal Of Hospitality Management, 24(3), 437-464. https://doi.org/10.1016/j.ijhm.2004.09.007

Lancaster, C., Bradley, E., Smith, I. K., Chessman, A., Stroup-Benham, C. A., \& Camp, M. (1997). The effect of PBL on students' perceptions of learning environment. Academic Medicine, 72(10), 10-12. https://doi.org/10.1097/00001888-199710001-00004

Louise, C. K., Angela,L., \& Kim, C. M. (2017). Problem-Based Learning and Civic Engagement in Undergraduate Education.Communication Disorders Quarterly, 39(1), 312-319. https://doi.org/10.1177/1525740116685184

Mamoon, M. (2012). Gender Differences in Mathematical Thinking and Mathematical Achievement in Jordanian 6th Grade. Al-Hussein Bin Talal University Jordan, 5(2), 523.

Meng, Y. T., \& Shuh, S. L. (2011). From Socialization to Internalization: cultivating technological pedagogical content knowledge through problem-based learning.Australian Journal of Educational Technology, 27(1). 89-104.

Mulhern, G., \& Wylie, J. (2004). Changing levels of numeracy and other core mathematical skills among 
psychology undergraduates between 1992 and 2002. British Journal of Psychology, 95(3), 355-370. https://doi.org/10.1348/0007126041528176

Nieswandt, M. (2001). Problems and possibilities for leaming in an introductorychemistry course from a $\begin{array}{lllll}\text { conceptual change perspective. Science } & \text { Education, }\end{array}$ https://doi.org/10.1002/1098-237x(200103)85:2<158::aid-sce40>3.0.co;2-3

Nowak, J. A. (2001). The implications and outcomes of using problem-based learning to teach middle school science (Doctoral dissertation).

Onder, I., \& Geban, O. (2006). The effect of Conceptual Change Texts Oriented Instruction on Students' Understanding of The Solubility Equilibrium Concept. Hacettepe University Journal of Education, 30, 166-173.

Pinarbasi, T., \& Canpolat, N. (2003). Students' understanding of solution chemistry concepts. Journal of Chemical Education, 80(11), 1328. https://doi.org/10.1021/ed080p1328

Savery, J. R. (2006). Overview of Problem-based Learning: Definitions and Distinctions. Interdisciplinary. Journal of Problem-Based Learnin, 1(1), 9-20. https://doi.org/10.7771/1541-5015.1002

Sirhan, G. (2007). Learning difficulties in chemistry: An overview.

Sugiharti, G., \& Bastian, J. H. (2018). Influence of Learning Model Using Laboratory and Numeric Ability to Student Learning Result on Thermochemical Material. International Education Studies, 11(5), 154-160. https://doi.org/10.5539/ies.v11n5p154

Sugiharti, G., \& Hasibuan, S. K. (2017). The Effect of Inquiry Learning Method by Using Laboratory and Logical Thinking on Learning Outcome in Chemical Reaction Rate. Jurnal Pendidikan Kimia, 9(1), 229-235. https://doi.org/10.24114/jpkim.v9i1.6184

Sugiharti, G., Abdul, H. K., \& Mukhtar, M. (2017). The Effect of Learning Model and Mathematical Ability into Student's Learning Outcomes in Evaluation Course of Chemistry Education State University of Medan, Proceeding of The 2nd Annual Internatioanal Seminar on Transformative Education and Educational Leadership (AISTEEL) Grand Mercure Hotel, 16-17. https://doi.org/10.2991/aisteel-17.2017.61

TIMSS and PIRLS. (2011). Hasil Pemetaan.

Visconti, C. F. (2010). Problem-based learning: Teaching skills for evidence-based practice. Perspectives on Issues in Higher Education, 13, 27-31. https://doi.org/10.1044/ihe13.1.27

Whitehill, T. L., Bridges, S., \& Chan, K. (2014). Problem-based learning (PBL) and speech-language pathology: A tutorial. Clinical Linguistics \& Phonetics, 28, 5-23. https://doi.org/10.3109/02699206.2013.821524

\section{Copyrights}

Copyright for this article is retained by the author(s), with first publication rights granted to the journal.

This is an open-access article distributed under the terms and conditions of the Creative Commons Attribution license (http://creativecommons.org/licenses/by/4.0/). 